\title{
Optimization of The Application of The Covid-19 Health Protocol for Elementary School Students in Banyuasin South Sumatera
}

\author{
Yustini Ardillah ${ }^{1, a)}$, Anggun Budiastuti ${ }^{11}$, Dian Safriantini ${ }^{1)}$ and Rendi Sabana ${ }^{2)}$ \\ ${ }^{1}$ Fakultas Kesehatan Masyarakat, Universitas Sriwijaya, Indralaya, Indonesia \\ ${ }^{2}$ Fakultas IImu Tarbiyah dan Keguruan, Universitas Islam Negeri Raden Fatah, Palembang, Indonesia \\ a)Corresponding author: yustini_ardillah@fkm.unsri.ac.id
}

\begin{abstract}
Covid-19 continues to increase the number of patients who are positive for Covid-19. Indonesia is a risky country to visit, while the National Data for South Sumatra is the number one province on Sumatra Island with the highest number of Covid-19 patients. Government policy allows regions or regions with yellow zones to open schools offline. Banyuasin Regency is included in the yellow zone of Covid patients, so teaching and learning has been carried out offline with strict implementation of health protocols. To support offline teaching and learning activities, it is necessary to educate students about the $3 \mathrm{M}$ movement (maintaining distance, using masks, washing hands with soap). This activity aims to train students to apply the $3 \mathrm{M}$ health protocol correctly. The results of the service show that there is an increase in knowledge and changes in student behaviour after receiving training and counselling about health protocols at school. Optimization of health protocols needs to be carried out on an ongoing basis to prevent the transmission of COVID-19 in elementary schools.
\end{abstract}

Key words: COVID-19, health protocol, Elementary School

\section{INTRODUCTION}

Corona Virus Disease 19 has changed the order of human life. The education system almost all over the world also experienced changes during this pandemic. The system that was originally face-to-face was immediately changed to online (Siahaan, 2020). After the pandemic lasted more than six months, several local governments allowed schools to carry out face-toface learning again accompanied by a rule that only schools were in the yellow and green zone areas.

The policy is accompanied by rules regarding the application of health protocols in schools for students and teachers in schools. The regulation is based on the fact that schools can become epicenters of Covid-19 transmission when school residents do not apply health protocols optimally. As happened in South Korea, They had to closed schools again after being opened due to the discovery of an increase in the number of Covid-19 cases in school-age children (Pradhan et al., 2020, Ramteke and Sahu, 2020). The implementation team's interview with several students in elementary schools found that health protocols in schools were often ignored. Socialization is only done at the beginning when the school starts, so as the teaching and learning activities progress, the implementation is getting less and less. There are hundreds of elementary school students in one school. The transmission of Covid-19 is very likely if the $3 \mathrm{M}$ movement (maintaining distance, wearing masks and washing hands with soap) is not implemented.

Banyuasin Regency is included in the yellow zone area, so it is allowed to carry out teaching and learning activities offline or face to face. This teaching and learning activity has been carried out during the month of September. Therefore, counseling on health protocols in schools needs to be carried out in order to ensure that all students and the school are able to optimally prevent COVID-19. Banyuasin Regency. This activity is counseling and practice of the $3 \mathrm{M}$ movement to elementary school students. 


\section{METHOD}

The target audience for this activity is the 200 students of the 27 Talang Kelapa public elementary school, Banyuasin. This community service team consists of lecturers and students. Four lecturers from Environmental Health Departmentthe Faculty of Public Health, Sriwijaya University in collaboration with Faculty of Science Education of Universitas Islam Negeri Raden Fatah Palembang. Meanwhile, the students who were part of this community service team were third-year students and alumni who have just completed their Bachelor of Public Health education at the Faculty of Public Health, Sriwijaya University.

The method of activity that carried out was to conduct counselling and outreach to the community in increasing knowledge and awareness of health protocols in elementary schools. The main activity was carried out in the form of counselling with the presentation method in front of elementary school students. To achieve the goals set, counselling participants were given material on the process of transmitting Covid-19, prevention with the $3 \mathrm{M}$ movement (keeping distance, wearing masks and washing hands with soap). In addition, distribution of flyers for washing hands with soap, how to use masks and cough etiquette. Through This activity, we also distributed masks and hand sanitizer to elementary school students.

\section{RESULTS}

Participants in this community service activity are elementary school students who are in grades four, five, and six. Activities are carried out according to the face-to-face schedule of students. State Elementary School 27 Banyuasin implements a schedule three times a week for each student to study face-to-face. Most of the participants in this activity were female or female, while the number of students for each class was almost the same, only sixth graders participated more and fourth graders participated the least.

Table 1. Participants' Characteristic $(\mathrm{N}=200)$

\begin{tabular}{|c|c|c|c|c|}
\hline No & Characteristic & & Frequency & $\begin{array}{c}\text { Percentage } \\
(\%)\end{array}$ \\
\hline \multirow[t]{3}{*}{1} & Sex & & & \\
\hline & Boy & & 85 & 42.5 \\
\hline & Girl & & 115 & 57.5 \\
\hline \multirow[t]{5}{*}{2} & Level & & & \\
\hline & Grade 4 & & 62 & 31 \\
\hline & Grade 5 & & 68 & 34 \\
\hline & Grade 6 & & 70 & 35 \\
\hline & & Total (N) & 200 & 100 \\
\hline
\end{tabular}

The counselling activity was carried out with three main materials, namely the movement of washing hands using soap properly, coughing and sneezing etiquette in public places, and the correct use of masks. Counselling activities using the lecture method and also demonstrations on the proper procedures for washing hands with soap, cough etiquette in public places, and the use of masks. To help students' understanding, leaflets are given containing the contents of counselling materials. In addition to counselling, this service activity also distributes threelayered cloth masks according to the standards of cloth masks that can be used. The purpose of this distribution is so that students who do not have masks can maximally use masks during teaching and learning activities at school. 


\section{Knowledge Assessment}

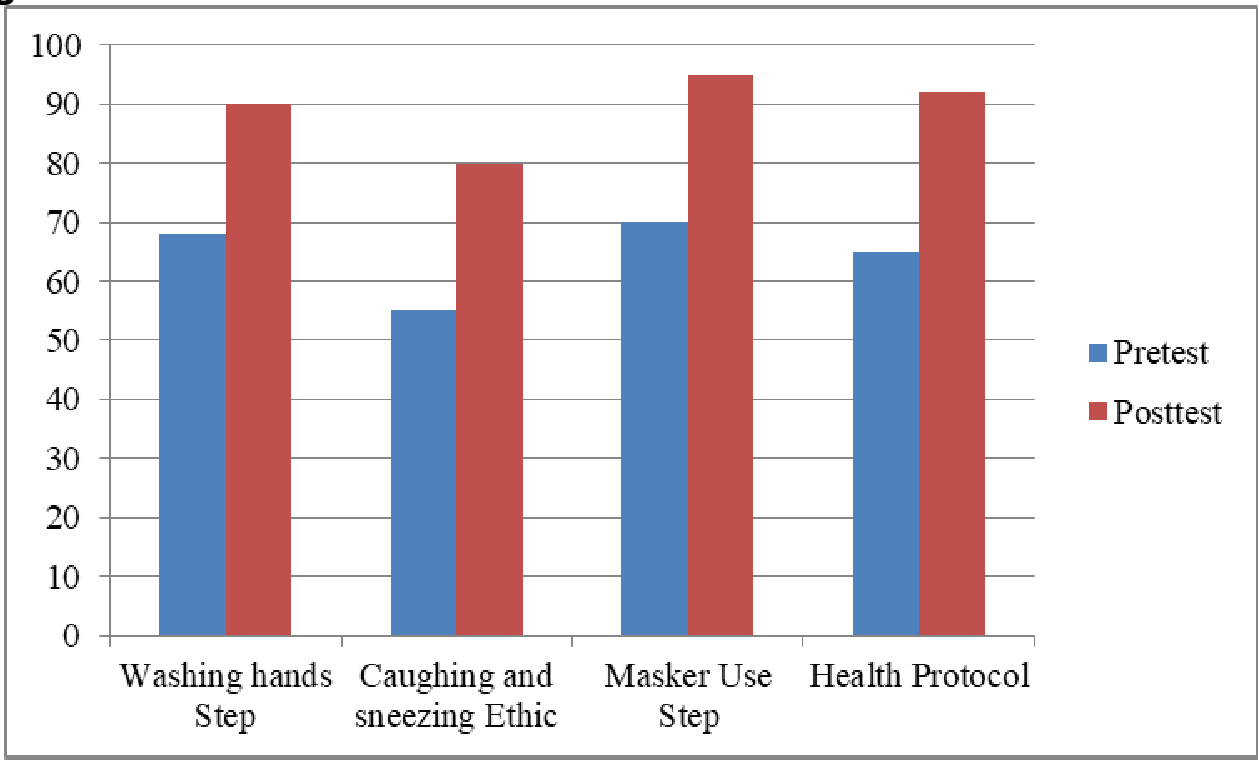

Figure 1. Pretest and Posttest Result

The evaluation of the activities was carried out by means of pre-test and post-test as well as interviews with principals and teachers in the target elementary schools. The results of the pre and post test showed an increase in knowledge before and after being given counselling. While behaviour was measured by interviews, the result was that teachers and school principals stated that the number of masks used in schools was $100 \%$ for 2 weeks after the counselling was carried out.

The results of the pre-test and post-test of students participating in this community service activity are summarized in Figure 1 . The results show that there is a change or increase in the average score of students from four categories of questions, namely how to wash hands, cough and sneeze etiquette, how to use masks and apply health protocol in school.

\section{DISCUSSION}

This community service activity was carried out in order to answer the problem of the low use of masks in the target schools and the $3 \mathrm{M}$ movement which had not been maximally carried out. Therefore, the target audience is very interested in participating in the visitation activities carried out by the community service team from the Faculty of Public Health, Sriwijaya University. In the implementation of this activity, the school community gave a positive response that such activities should be carried out periodically so that the target audience is able to change their behaviour. Students and other school staff are expected to be more aware of carrying out the $3 \mathrm{M}$ movement, namely maintaining distance, washing hands with soap and using masks in a disciplined manner so that COVID-19 prevention can be maximized. The activity that was carried out by Suhartati et al. (2020) resulted that the public was enthusiastic to get information about COVID-19 with direct counselling methods. This activity was also supported by Syapitri et al. (2020) where activities that can directly touch the community are highly expected by the target audience.(Rahmawati et al., 2020a)

The implementing team for community service activities from the Faculty of Public Health, Sriwijaya University conducted visitation activities to the target audience. This activity was carried out by conducting counseling/explanation of material about the $3 \mathrm{M}$ movement, namely maintaining distance, using masks and washing hands with soap. The demonstration and presentation of the material was guided by the community service implementation team using the presentation method. Demonstrations were carried out in the form of correct use of masks, and six steps of how to wash hands with soap. Many activities like this have been carried out with different audiences and targets. Previous activities still touched the community in general (Sinaga et al., 2020). 
Counselling is carried out in order to increase the knowledge and skills of school students about health protocols in schools in the form of the $3 \mathrm{M}$ movement, namely using masks, maintaining distance and washing hands with soap. The results of the counselling post-test got an increase in the average score of the knowledge value of the participants. This activity was also carried out by Listina et al. (2020) distributing posters to the general public with the result of increasing public understanding. Meanwhile, according to Rahmawati et al. (2020b) with early childhood participants, activities like this are additional knowledge for early childhood children.

\section{CONCLUSIONS AND RECOMMENDATIONS}

Optimizing health protocols in schools such as counseling on the $3 \mathrm{M}$ movement, namely maintaining distance, using masks and washing hands with soap, needs to be carried out continuously to maximize the prevention of transmission of the COVID-19 virus in schools.

\section{ACKNOWLEDGMENTS}

We express our gratitude to Allah Subhanahu Wa Ta'ala, because for the facilities provided so that this Community Service can run smoothly. This community service can be carried out well with the support of The Sriwijaya University Research and Community Service Institute as a funder for this community service activity in 2020.

\section{REFERENCES}

Listina, O., Solikhati, D. I. K. \& Fatmah, I. S. (2020). Edukasi corona virus desease 19 (covid-19) melalui penyebaran poster kepada masyarakat kecamatan slawi kabupaten tegal. JABI: Jurnal Abdimas Bhakti Indonesia, 1, 10-10.

Pradhan, D., Biswasroy, P., Ghosh, G. \& Rath, G. (2020). A review of current interventions for covid-19 prevention. Archives of medical research.

Rahmawati, N. V., Utomo, D. T. P. \& Ahsanah, F. (2020a). Fun handwashing sebagai upaya pencegahan covid-19 pada anak usia dini. Jurnal Masyarakat Mandiri, 4, 218.

Rahmawati, N. V., Utomo, D. T. P. \& Ahsanah, F. (2020b). Fun handwashing sebagai upaya pencegahan covid-19 pada anak usia dini. JMM (Jurnal Masyarakat Mandiri), 4, 217-224.

Ramteke, S. \& Sahu, B. L. (2020). Novel coronavirus disease 2019 (covid-19) pandemic: Considerations for the biomedical waste sector in india. Case Studies in Chemical and Environmental Engineering, 100029.

Siahaan, M. (2020). Dampak pandemi covid-19 terhadap dunia pendidikan. Dampak Pandemi Covid-19 Terhadap Dunia Pendidikan, 20.

Sinaga, L. R. V., Munthe, S. A. \& Bangun, H. A. (2020). Sosialisasi perilaku cuci tangan pakai sabun di desa sawo sebagai-bentuk kepedulian terhadap masyarakat ditengah mewabahnya virus covid-19. Jurnal Abdimas Mutiara, 1, 19-28.

Suhartati, R., Mardiana, U. \& Nurpalah, R. (2020). Pemberdayaan masyarakat dalam penggunaan hand sanitizier dan masker sebagai upaya preventif terhadap covid-19. BANTENESE: JURNAL PENGABDIAN MASYARAKAT, 2, 26-33.

Syapitri, H., Siregar, L. M. \& Saragih, F. L. (2020). Pencegahan penularan covid-19 melalui sosialisasi dan pembagian masker di pasar pringgan medan. Jurnal Kreativitas Pengabdian Kepada Masyarakat (Pkm), 3, 422-29. 


\section{APPENDIX}

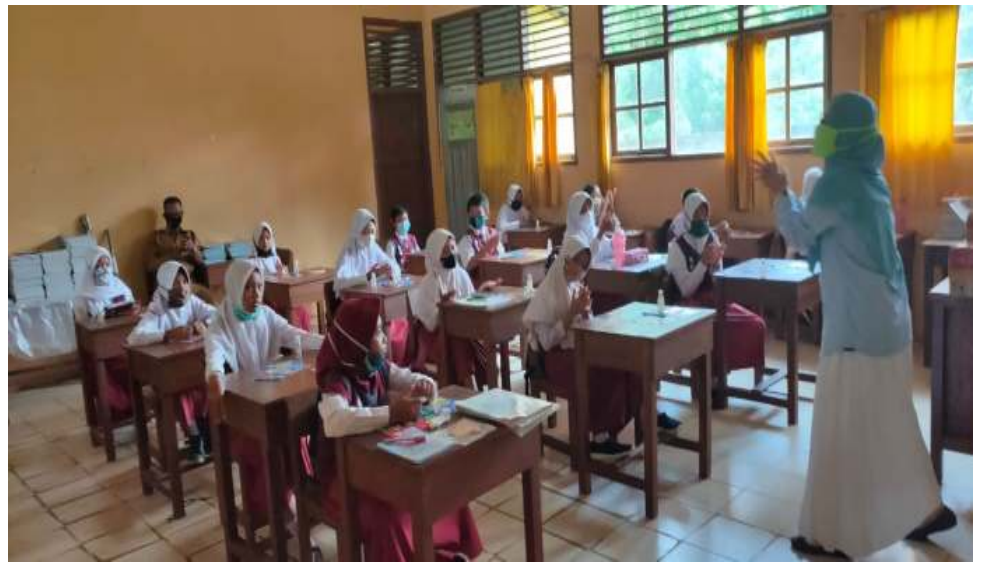

Figure 2. Demonstration of the Six Steps of Hand Washing Using Hand Sanitizer

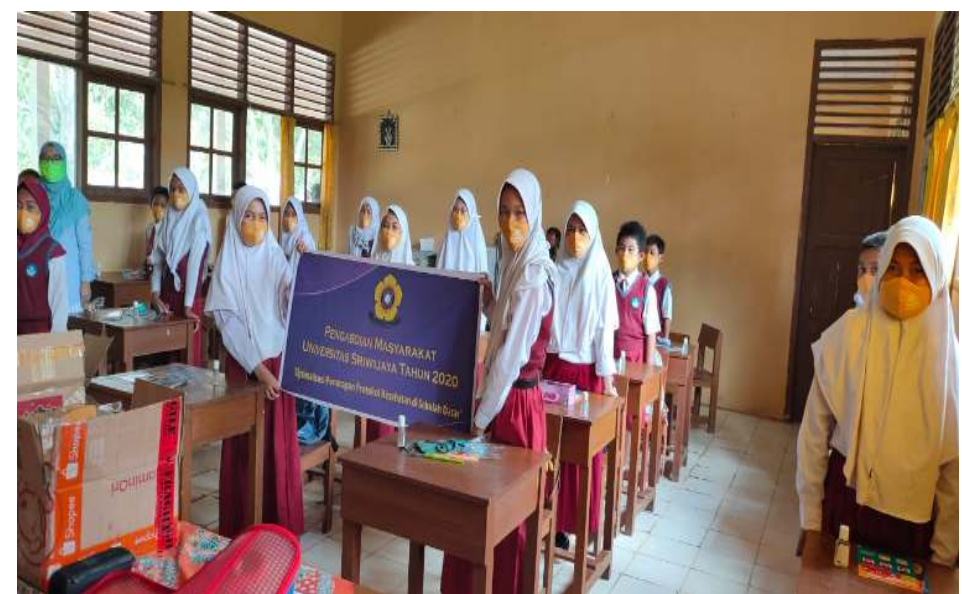

Figure 3. Wearing of masks together 